\title{
Cultural Political Economy of Competitiveness, Competition and Competition Policy in Asia
}

Ngai-Ling Sum

Lancaster University, Politics, Philosophy, and Religion, County South, Lancaster, United Kingdom*

*Email: n.sum@lancaster.ac.uk

ORCID iD: 0000-0002-4285-1351

Distinktion: Scandinavian Journal of Social Theory, 2015, 16 (2): 211-228

http://dx.doi.org/10.1080/1600910X.2015.1059771

This article employs cultural political economy to explore, interpret, and explain the articulation of competition, competitiveness, and competition policies in Asia in the current neoliberal era. It describes how this approach explores social order and changes in terms of the interaction between semiosis and structuration in the context of four types of selectivity: structural, agential, discursive, and technological. It then outlines an analytical framework and methodology to apply this approach to the chosen case study. This concerns how these modes of selectivity have operated since the 1997 'Asian Crisis' to produce changes in the policy discourses and practices of the World Bank and its Asian regional agencies with the declared aim of reducing poverty, enhancing competitiveness, and promoting corresponding forms of competition policy. Next it examines how these discourses and practices are assembling a new dispositive around an emerging disciplinary and governmentalized socioeconomic-cum-legal order in the wake of the Doha conjuncture in Asia. The concluding remarks address some tensions and challenges in the making of this competitiveness order in Asia.

Keywords: Asian Development Bank; competition policy; competitiveness; cultural political economy; discourse; dispositive; poverty reduction; selectivity; World Bank. 


\section{Introduction}

This article uses a cultural political economy approach to explore, interpret, and explain the articulation of competition, competitiveness, and competition policies in Asia in the neoliberal era. It comprises four parts. First, it outlines how this approach explores the reproduction and transformation of social order in terms of the interaction between semiosis and structuration in the context of four types of selectivity: structural, agential, discursive, and technological. This part also outlines the analytical framework and methodology deployed in the accompanying case study. Second, it examines how the four modes of selectivity have interacted since the 1997 'Asian Crisis' to produce changes in the policy discourses and practices of the World Bank and its Asian regional agencies with the declared aim of reducing poverty, enhancing competitiveness, and promoting corresponding forms of competition policy. Third, it investigates how a new dispositive is being assembled through these discourses and practices around an emerging disciplinary and governmentalized socioeconomic-cum-legal order in the wake of the post-Doha conjuncture in Asia. Fourth, some concluding remarks identify some tensions and challenges in the making of this competitiveness order in Asia.

\section{Cultural political economy}

Cultural political economy (hereafter CPE) is a broad theoretical current that integrates the 'cultural turn' (i.e., a concern with discourse and inter-subjective meaning-making) with critical political economy (for an extended discussion, see Sum and Jessop 2013). It differs from the post-Marxist discourse analysis and constructivist approaches, which tend to focus one-sidedly on the constructive, performative role of ideas and discourses and to neglect the specific features and dynamic of the capitalist order. Whereas post-Marxist discourse analysis (e.g., Laclau and Mouffe 1985) follows de Saussure in highlighting the arbitrary, conventional relationship between signifier and signified, the CPE approach also explores actual or potential referents of signification in the real world ${ }^{1}$ (Sum and 
Jessop 2013: 164-8, 178-80). It argues that discourse involves more than an arbitrary play of signifiers confined to a linguistic or symbolic realm because the selection, retention, and institutionalization of discourses depends in part on structural, technological, and agential selectivities and the potential for social transformation in the 'extra-discursive' realm. This interest in the relation between the semiotic and extra-semiotic also distinguishes CPE from constructivist approaches (e.g., Blyth 2002). For, paraphrasing Orwell, while all construals are equal as significations, they are not equally performative. Only some construals get selected and retained as the basis for constituting, institutionalizing, and reproducing social relations and this depends, as noted, on all four kinds of selectivities.

\section{On Marx, Gramsci and Foucault}

One way to explore the interface between the semiotic and extra-semiotic is to stage an encounter between Marx, Gramsci and Foucault (Sum and Jessop 2013: 203-14). While Marx provides the crucial foundations for the critique of political economy, Gramsci developed a 'vernacular materialism' (Ives 2004) that highlights the role of language in sense- and meaning-making in mediating hegemony and domination across all spheres of society (Gramsci 1971; see also Thomas 2009; Green 2011). CPE enhances this synthesis by integrating Foucault's insights on objectivation, subjectivation, power/knowledge, and their associated technologies of power. He notes that technology has a Greek root (techné) that relates to arts, crafts, gadgets, knowledge, skills, and tactics (Rooney 1997). Thus, for Foucault, technologies, considered as arts of governing, have the potential to constitute objects, create subject positions and recruit subjects, and, in particular, create power/knowledge relations and thereby facilitate disciplinary and governmental power (Foucault 1991 and 1995). Combining the concepts, insights, and explanatory principles of these three radical theorists and activists can generate a productive heuristic for exploring the role of discourses and articulation as dispositives (see below) in the reorganization and consolidation of power relations. 
Figure 1 An Encounter between Gramsci, Marx and Foucault

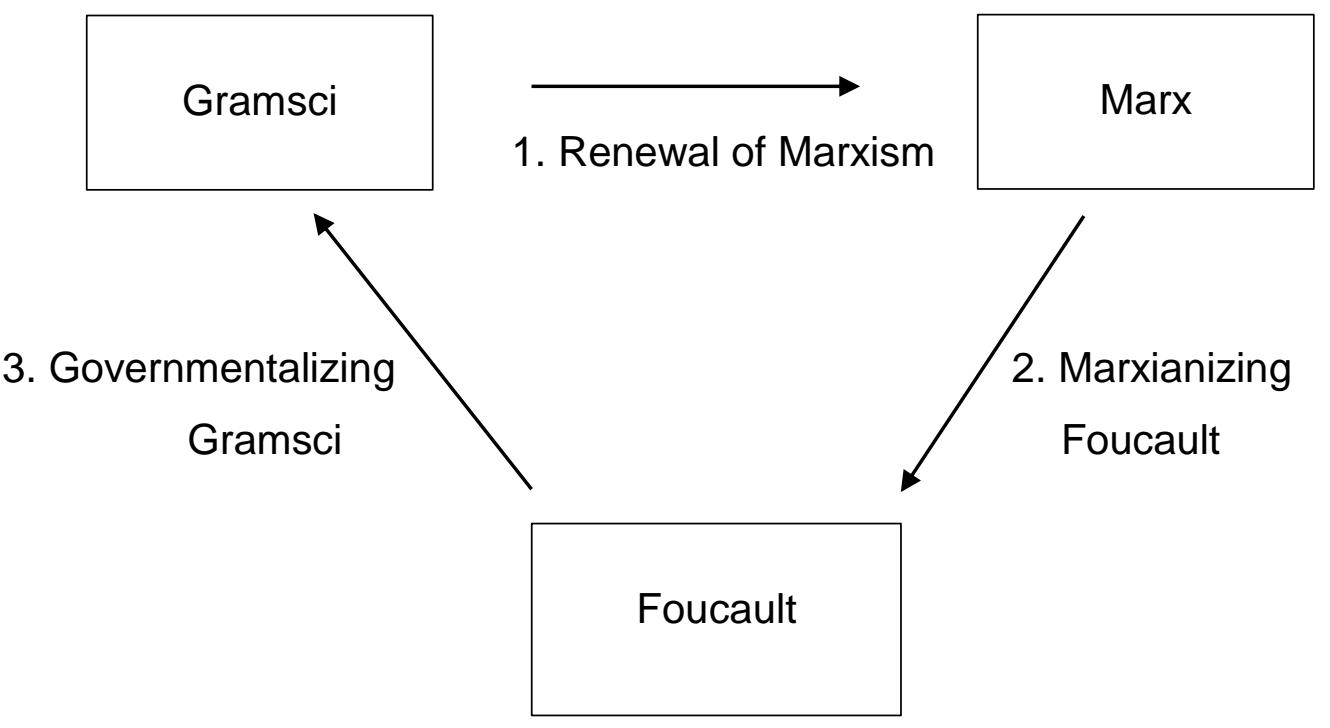

Source: Sum and Jessop 2013: 206.

This three-sided encounter involves a triple movement that helps to resolve the paradox identified in Marsden's aphorism: Marx tells us why, but cannot tell us how, and Foucault tells us how, but cannot tell us why (Marsden 1999: 135). First, Gramsci's vernacular materialism and strategic focus renew the Marxian critique of political economy with categories (e.g., hegemony) to analysis how as well as why. Second, this renewed Marxism provides the categories to reconnect Foucault's analyses to critical political economy. Third, Foucault enables the governmentalization of Gramsci through his interest in technologies of power as well as objectivation and subjectivation (see Figure 1; for further discussion, see Sum and Jessop 2013: 205-214). This subsection now presents two of the topics at stake in this encounter.

The first concerns certain parallels (and tensions) between Gramsci's account of the creative and performative role of hegemony in constituting power relations and Foucault's analysis of the productive and constitutive role of 'regimes of truth'. 
Hegemony problematizes the relationship between particular and universal interests in positing, promoting and sustaining a collective will (e.g., the 'national-popular' interest) through political, intellectual and moral leadership backed by a judicious mix of symbolic and material concessions and protected by the armour of coercion. Likewise, truth regime problematizes the 'truth effects' created and instituted through discourses, social practices, and what one might refer to as 'knowledging technologies'. Truth regimes produce object fields, subject positions and forms of power/knowledge that enable the assembling of dispositives. For Foucault, dispositive is a 'decidedly heterogeneous ensemble' that includes elements such as 'discourses, institutions, architectural structures, prescriptive decisions, laws, administrative measures, scientific statements, philosophical, moral or philanthropic propositions, in short: words, but also what is not expressed in words' (Foucault 1980: 194). These arguments have been developed by the Duisburg School of discourse analysis, which is inspired by Foucault's work on discourse and dispositive and the role of power/knowledge relations to construct truth regimes and consolidate power relations in specific apparatuses (dispositives) (see Link 1983; Jäger and Maier 2009; Caborn 2007). In the spirit of Gramsci and Foucault, this school argues that the mutual constitution of discourse and dispositive tends to sediment systems of power and/or rule and that the 'grammar' of the hegemonic or dominant discourses also limits alternatives and the capacities to resist hegemony and domination.

A second aspect concerns the constraints on constituting objects of governmentality through the co-construction of discourses and dispositives. Strategic interventions cannot be reconfigured at will or be actualized according to a pregiven plan. Indeed, they routinely produce uneven, unintended and even contradictory effects because of the recalcitrance of the raw materials that they seek to govern, the plurality of rival projects concerned to transform and govern these materials, and the resistance that such projects generate. Foucault $(1991,2008 a, 2008 b)$ recognized these issues in his lectures on governmentality and statecraft (see also Jessop 2010). Revisiting Marx (especially through a Gramscian optic) helps to identify the roots of these obstacles in the contradictions, crisis-tendencies and antagonisms of capitalist social formations that render them recalcitrant as 'objects' of governance and provide the motives and capacities for its 'subjects' to resist. This is important for the ensuing 
analysis because of Marx's ground-breaking contributions to the analysis of competition and its various modalities and scales in the contradictory and conflictual dynamic of differential accumulation.

Consistent with this encounter, CPE identifies four general modes of selectivity: structural, discursive, technological, and agential selectivities (see Sum and Jessop 2013: 214-29 and below). Focusing on these provides one analytical entry point to specific case studies of struggles over hegemony, especially as the relative weight of these selectivities varies over time and in different conjunctures. Indeed, it is their interaction that conditions the variation, selection, and retention of hegemonic, subhegemonic, and counterhegemonic projects and their societal repercussions and contradictions. . Nonetheless, whatever the research problem and the chosen entrypoint, attention should turn sooner or later to their contingent coevolution and how these selectivities may become crystallized into specific 'discourse-dispositive' assemblages. I now elaborate some key concepts in this regard.

\section{Four modes of selectivity in social relations}

The CPE approach distinguishes four kinds of selectivity that enable variation, shape selection processes, and influence retention (see Table 1).

Structural selectivity denotes the asymmetrical configuration of structural constraints and opportunities on social forces as they pursue particular projects. This configuration exists only insofar as it is reproduced in and through social practices and can be transformed through time, through cumulative molecular changes and/or more deliberate attempts to transform the pattern of constraints and opportunities. Whether these attempts succeed or not, they are likely to have path-dependent legacies.

Discursive selectivity is also asymmetrical. It comprises the asymmetrical constraints and opportunities inscribed in particular genres, styles, and discourses (or, more generally, particular forms of discourse) in terms of what can be enunciated, who is authorized to enunciate, and how enunciations enter intertextual, interdiscursive, and contextual fields. Semiotic resources set limits to what can be 
imagined, whether in terms of 'objects', possible statements within a discursive formation, themes that can be articulated within a given semantic field, or subject positions that can be adopted. Critical discourse analysis provides important analytical tools for studying these issues (e.g., Andersen 2003; Fairclough 2003). Furthermore, different forms of discourse and/or genres position subjects and agents in specific situations. A related set of selectivities concerns the extent and grounds that make some discursive forms more or less accessible to some agents rather than others either because of their sense- and meaning-making competence and their discursive competence in relation to everyday interactions or the demands of socialization into specialized discourses (e.g., neoclassical economics, law, and statistics). Foucauldian discourse analysis has much to offer here in terms of conceptual architectures and semantic fields.

\section{Table 1 Four Modes of Selectivity}

\begin{tabular}{|c|c|c|}
\hline Modes & Grounded In & Effects \\
\hline Structural & $\begin{array}{l}\text { Contested reproduction } \\
\text { of basic social forms } \\
\text { (e.g., capital relation, } \\
\text { nature-society relations), } \\
\text { their instantiation in } \\
\text { institutional orders and } \\
\text { organizational forms, and } \\
\text { in specific interaction } \\
\text { contexts }\end{array}$ & $\begin{array}{l}\text { Structures are not absolute constraints on } \\
\text { all actors equally but necessarily favour } \\
\text { some interests, identities, agents, spatio- } \\
\text { temporal horizons, strategies, and tactics } \\
\text { over others. } \\
\text { Path-dependency limits the scope for path- } \\
\text { shaping. }\end{array}$ \\
\hline Discursive & $\begin{array}{l}\text { Semiosis as a process of } \\
\text { selective sense- and } \\
\text { meaning-making required } \\
\text { so that agents can 'go } \\
\text { on' in the face of } \\
\text { complexity. } \\
\text { Operates at all scales } \\
\text { from the micropores of } \\
\text { everyday life to societal } \\
\text { self-descriptions. }\end{array}$ & $\begin{array}{l}\text { Sense- and meaning-making shape } \\
\text { perception and social communication. } \\
\text { Discursively-inscribed selectivities frame } \\
\text { and limit possible imaginaries, genre } \\
\text { chains, arguments, subjectivities, social } \\
\text { and personal identities, and the scope for } \\
\text { hegemony, sub- and counter-hegemonies. }\end{array}$ \\
\hline Technological & $\begin{array}{l}\text { Technical and social } \\
\text { forces and relations in } \\
\text { and of production }\end{array}$ & $\begin{array}{l}\text { These technologies condition the } \\
\text { appropriation and transformation of nature, } \\
\text { create the built environment, and shape }\end{array}$ \\
\hline
\end{tabular}




\begin{tabular}{|l|l|l|}
\hline & $\begin{array}{l}\text { Normalizing, disciplinary } \\
\text { and governmental } \\
\text { technologies linked to } \\
\text { specific mechanisms and } \\
\text { sites of intervention tied } \\
\text { to power/knowledge } \\
\text { relations }\end{array}$ & $\begin{array}{l}\text { dynamics in different fields in the social } \\
\text { and spatio-temporal division of labour } \\
\text { These technologies produce objects and } \\
\text { subjects, shape anatomo- and bio-politics, } \\
\text { create truth regimes, divide and coordinate } \\
\text { social action, and co-constitute } \\
\text { dispositives }\end{array}$ \\
\hline Agential & $\begin{array}{l}\text { Specific capacities of } \\
\text { specific (sets of )social } \\
\text { agents to 'make a } \\
\text { difference' in particular } \\
\text { conjunctures thanks to } \\
\text { idiosyncratic abilities to } \\
\text { exploit the three other } \\
\text { kinds of selectivity }\end{array}$ & $\begin{array}{l}\text { Making a difference depends on abilities to } \\
\text { (1) read conjunctures and identify the } \\
\text { scope for action; (2) re-activate and re- } \\
\text { articulate sedimented discourses; (3) remix } \\
\text { extant social technologies or invent new } \\
\text { ones; (4) deploy strategies and tactics to } \\
\text { shift the balance of forces in space-time. }\end{array}$ \\
\hline
\end{tabular}

Source: Abridged version of Table 5.1 (Sum and Jessop 2013: 218-9).

Technological selectivities have two referents in CPE. In broad terms, they include the full range of forces of production and technical and social relations of production involved in the social division of labour. Marx and Gramsci have much to contribute to the analysis and critique of their selectivities and, as we shall see, they are crucial to understanding the nature of economic and societal competitiveness. Foucault, while not neglectful of this set of referents, is more interested in: (1) the microtechnologies of power involved in constituting objects and creating subject and intersubject positions; and (2) the technologies of disciplinary and governmental power and their relation to truth regimes - in regard to which one might call them 'knowledging technologies'. These are important aspects of his more general analysis of the discourse-dispositive nexus and the limits that this nexus sets to imagining radical alternatives and implementing transformative projects (see below).

Agential selectivity refers to the differential capacity of individual agents or specific social forces with specific identities and interests to interpret and act upon the asymmetrical constraints and opportunities entailed in the three other kinds of selectivity. Social actors can make a difference thanks to their relative capacities read particular conjunctures, articulate or re-articulate social imaginaries and translate them into discourses and feasible projects, deploy old or new technologies 
of power, and engage in wars of position and/or manoeuvre (see also Table 4, which applies some of these categories to interpret and illustrate a particular case study).

\section{A CPE of competiveness, competition and competition policy: the making of a pro-poor neoliberal regime in Asia}

I now apply selected categories and arguments to examine the micro-construction of a new hegemonic project for the Asian region (defined below) that was articulated around competitiveness and competition in response to the failure of the Doha Round when a coalition of developing countries managed to block further global neoliberal market reforms. This prompted organic intellectuals to search for alternative strategies to achieve similar objectives on a macro-regional scale by exploiting the prevailing structural, discursive, and technological selectivities in this conjuncture to make a difference through a skilful articulation of micro-level and meso-level practices to extend and consolidate neoliberal hegemony. Methodologically, CPE draws on the critical political economy literature on neoliberal restructuring (e.g., Harvey 2005; Saad-Filho and Johnson 2004; Plehwe and Walpen 2006) and critical discourse analysis (especially the Duisburg School, e.g., Link 1983 and Jäger and Maier 2009). The remainder of this article illustrates the CPE approach in terms of agential, discursive and technological selectivities. In particular, it examines the role of organic intellectuals in extending and applying fields of knowledge such as 'new institutional economics'; and it also explores the objectivation of competition and competitiveness and the construction of a new intersubjective space based on competitive-useful subjects (subjectivation) ties to specific technologies of power and knowledge. To illustrate what is at stake here, it draws on a range of texts such as policy speeches, policy documents, outlooks, policy toolkits, etc. related to competitiveness and competition policy. These discursive instruments have their own discursive and technological selectivities that emerge at particular conjuncture when nodal agencies such as major economists playing particular roles.

The structural context: the WTO's Doha Round and beyond 
During the protracted Doha Round organized by the World Trade Organization (WTO), developed countries and multinational corporations sought to deepen the neoliberalization of the global economy. They encountered strong resistance from developing countries supported by NGOs on the grounds that market opening would allow large transnational corporations to gain a bigger market share in their economies without securing reciprocal advantages in developed economies (Altay 2011: 117 and 159-60). In Asia, this might threaten national industrial champions and undermine their exportist modes of accumulation (Jessop and Sum 2006: 152186). In the trade negotiations at the Cancún Ministerial Meeting in September 2003, faced with this resistance, the WTO withdrew its proposals for a global competition policy regime. Indeed, in its subsequent 'July 2004 package', which was formally adopted on 1 August 2004, the WTO General Council announced that competition policy issues would be excluded from the WTO Work Programme for the Doha Round.

This tactical retreat, which did not end the WTO's support for a global competition policy regime, occurred at the critical juncture of the transition from Washington to post-Washington Consensus. As the dominant global economic paradigm between 1980 and 1997, the Washington Consensus promoted an unregulated, liberalized and privatized space potentially embracing the world market and with the potential for capital to colonize world society. The trade and financial liberalization and associated policies proposed by the IMF, WTO and World Bank for developing countries generated both blowback and backlash. In Asia, they stimulated financial speculation, a boom in real estate, and economic and social polarization. They also created the conditions for the 1997 Asian crisis with its debt crisis, structural economic crisis, and mass unemployment - which provided the excuse and rationale for more vigorous imposition of IMF conditionalities such as fiscal austerity, neoliberal structural reforms, and privatization (Beeson and Robison 2000: 3-24). Accordingly the Bretton Woods institutions were subject to criticisms and protests from Asian states and their business allies and, more vociferously, from local and transnational NGO networks.

Unsurprisingly, this made Asian political and social forces extra-defensive about the extension of neoliberalism envisaged in the Doha Round. Thus global and regional 
actors searched for more palatable (but still neoliberal) development imaginaries and for new policy discourses and institutions that could secure them. They began to explore new theoretical/policy orientations, institutional entry-points and new sites and scales of action that would recast and deepen the neoliberal thinking. This search process culminated in the so-called post-Washington Consensus. Important elements of this new approach were reworked discourses and related practices such as competitiveness, poverty reduction, pro-poor, knowledge-sharing, good governance competition, etc. (cf. St Clair 2006). These shifted the focus of neoliberal policy formulation and implementation from the Doha Round, especially following the forced retreat in 2004, to other sites and scales of action. These included other international organizations (notably the World Bank, UNCTAD, and OECD), worldwide networks (such as the US-sponsored International Competition Network) and regional organizations (including the EU and the Asian Development Bank). In particular, the World Bank and its regional counterparts became major forums for promoting competition policies. Discursively, especially after the Asian crisis, the World Bank was experimenting with a new economic language and practices that, it claimed, could remedy market failures. For example, addressing the World Bank Board of Governors after the crisis, the then World Bank President James Wolfensohn claimed:

Too often we have been too narrow in our conception of the economic transformations that are required - while focusing on macroeconomic numbers, or on major reforms like privatization, we ignored the basic institutional infrastructure, without which a market economy simply cannot function (Wolfensohn 1998: 11-12)

This discursive shift from the market-oriented Washington Consensus was supported and grounded in the 'new institutional economics', which emphasized 'getting institutions right'. Thus institutions such as property rights, contract legislations and belief systems are seen to affect economic performances as they bring security and reduce uncertainty with economic transactions (e.g., North 1990). This institutional turn was also endorsed by the newly appointed chief economist of the World Bank, Joseph Stiglitz, who called for institutions and states to complement market forces by: (1) developing regulatory frameworks (e.g., anti-trust law) for market competition 
(see case study below); (2) reinvigorating institutions to build administrative and technical capability; (3) instituting rules and norms that incentivize officials to act in the collective interest; and (4) creating partnerships between states, private sectors and civil society actors, etc. (Stiglitz 1989; Stiglitz with Chang 2001: 40-5). The institutional turn and its associated discursive shifts mediated the transition from the free market-oriented Washington Consensus towards the post-Washington Consensus and its neoliberal governance agenda (see below). While this agenda was pursued at many sites, this article will now concentrate on its promulgation and instantiation in Asia, which is defined, for present purposes, as the economies that fall under the remit of the Asian Development Bank.

\section{Agential and discursive selectivities of the World Bank/Asian Development Bank (ADB): 'Knowledge Bank' and knowledge brand}

In parallel with the reinvention of the neoliberal discourse at the global scale of the World Bank, there were efforts to translate it at the macro-regional, national and subnational scales through more or less skilful exploitation of agential, discursive and technological selectivities. Key roles in this regard were played by global/regional organizations, development agencies, policy commissions, policy advisors, business leaders, chambers of commerce, management consultants, competition professionals, trainers, etc. These diverse agents operate within the global-regional circuits of policy knowledge and aim to satisfy the demand for fast policy (see Peck and Theodore 2015). Apart from the policy discourses on 'getting institutions right', other narratives in global policy circuits included: (1) 'getting knowledge management right' (e.g., Wenger 1999) based on sharing information and enhancing the capacities of relevant communities of actors; and (2) 'getting competitiveness right (e.g., Porter 1990 and, Lundvall 1992) with a view to promoting growth and development, These narratives have been selectively combined to rebuild neoliberal hegemony at the World Bank and its regional counterparts such as the Asian Development Bank.

The World Bank/ADB's identity as a 'knowledge bank' 
Key players in the World Bank and ADB have pursued a new knowledge management strategy since 1996. This allowed them to reorient and redefine their identity from a traditional lending institution to 'The Knowledge Bank'. It mobilized stakeholders (e.g., governments, private sectors, NGOs; foundations and judicial bodies) to co-produce development ideas/advice for subsequent dissemination to developing countries. This rebranding has strengthened their image as experts in constructing and transmitting development knowledge (Murphy 2007: 77). From a CPE viewpoint, there are two key questions about these attempts to remake neoliberal hegemony: what development knowledge is being selectively constructed/transmitted; and what is being (de-)valued by the Banks? To answer these questions, we need to consider the agential, discursive, and technological selectivities of the World Bank and ADB.

First, knowledge about 'getting institutions right' (see above) was a key element in the two banks' agential and discursive selectivities. In agential terms, the appointments of James Wolfensohn as the new President in 1995 (until 2005) and of Joseph Stiglitz as the Chief Economist from 1997 (until 2000) enabled these organic intellectuals to reorient and renegotiate the Bank's knowledge base away from neoclassical economics. Not without their critics, the two leaders with the support of teams of academic-consultants (Wade 2001: 129-130) rolled out their version of 'new institutional economics' under the Bank's poverty-reduction-growth policy framework. This included the development of good governance, getting regulatory and institutional fundamentals right, building public services and infrastructure, etc. (Cammack 2003: 10; Taylor and Soederberg 2007: 455). This discursive imprint can be discerned in several World Bank knowledge products (e.g., development reports and programmes) between 1997 and 2005. Together they constructed a new (inter)discursive space that gave a new sense and meaning to 'development'. Starting from the World Development Report 1997: The State in a Changing World and moving through several reports to the 2005 publication, A Better Investment Climate for Everyone, ideas such as the need for 'capable states' to support markets formed the basis for the subsequent discursive articulation and interweaving with pro-poor growth rhetoric, narratives, policies and programmes (see Table 2). More specifically, 'capable states' are narrated as agents that support and complement market forces, especially in creating the right regulatory environment for private 
sector competition. The role of state institutions in this regard include developing competition policy/law, antitrust legislation, good governance judicial development, etc., are valued as they are said to be able to mitigate market distortion, improve investment climate and create jobs and reduce poverty (World Bank 2005: 95-106).

The selective integration of 'private sector competition' into a poverty reduction agenda by the World Bank can be examined on two levels. First, the neoliberal narrative about 'market distortion' that required rigorous competition policy/law to counteract domestic monopoly conditions (e.g., cartels, price-setting activities, etc.) was retained in the name of promoting private sector competition. Second, drawing on 'new institutional economics', this neoclassical version was rearticulated to emphasize the importance of 'getting institutions right' as an integral part of development policy. It is ineffective institutions (e.g., corruption, rigidity, information problems) that are now said to prevent or hinder the poor from engaging effectively with the market. In other words, this modified competition gaze combined the old market 'distortion' view of neoclassical economic with the new 'states complement markets' perspective of 'new institutional economics'. It is by balancing 'markets' and 'governance' that a 'good institutional fit' can be achieved that, in turn, is expected to reduce 'barriers to competition' via competition law and competition policy. In short, this genre chain ${ }^{2}$ both selectively expands and limits development imagination. It expands development in a pro-poor and participatory direction; but it also selectively limits it to the neoliberal rhetoric and practices of 'market distortion', 'private sector competition' and intervention via the development of competition policy and law and related measures. This new round of knowledge on structural adjustment reasserts neoliberal control by seeing competition not as a natural process but as a development tool that needs to be institutionalized and produced by getting the 'competition policy and competition law right'. In this regard, the agential and discursive selectivities favoured technical and juridical means to make the postWashington Consensus.

\section{Table 2 Examples of the Global-Regional Knowledge Products Conducive to the Making of Competitiveness-Competition Regime in Asia}




\begin{tabular}{|l|l|l|}
\hline Scales & $\begin{array}{l}\text { Examples of } \\
\text { Institutions } \\
\text { Involved }\end{array}$ & $\begin{array}{l}\text { Examples of Knowledge Products Related to } \\
\text { Pro-Poor Growth, Competitiveness and } \\
\text { Competition Policy/Law }\end{array}$ \\
\hline Global & World Bank & $\begin{array}{l}\text { Poverty Reduction Strategy Papers } \\
\text { World Development Reports 1997and } 2005\end{array}$ \\
\hline Regional & $\begin{array}{l}\text { Asian } \\
\text { Development } \\
\text { Bank/ADBI }\end{array}$ & $\begin{array}{l}\text { Asian Development Outlook 2003 } \\
\text { Competition Law Policy Roundtable 2006 } \\
\text { Competition Law Toolkit 2006 } \\
\text { AEGC Workshops 2008-2010 }\end{array}$ \\
\hline
\end{tabular}

Source: Author's own compilation

$A D B$ discursive thickenings: 'Knowledge Bank' appropriating knowledge brand

These discursive changes on the global level were translated to the regional scale. For example, the ADB echoed the World Bank's identity as a 'knowledge bank' and its new institutional approach to competition law and policy. Indeed, to increase the reverberation of the World Bank's new discourse in the region, the ADB added another discursive layer to the construction. It thickened it by linking competition, competition law and policy to the idea of 'competitiveness'. Discourses on 'competitiveness' are widely circulated in and across global, regional, national and subnational policy circuits. I have argued elsewhere that these discourses are condensed into 'knowledge brands' (Sum 2009). A knowledge brand is a set of hegemonic meaning-making discourses and linked dispositives promoted by 'worldclass' guru-academic-consultants (e.g., Michael Porter, Harvard Business School, Bain, and Boston Consulting Group) who claim unique knowledge of, and insight into, the economic world and its wider social context. It is readily translatable and combinable with other brands and can be turned into pragmatic policy recipes and toolkits (e.g., indexes, outlooks, guidelines, best practices). It identifies potentials for change and appeals to the pride and anxieties of subjects experiencing socioeconomic change during periods of uncertainty.

One of the most significant brands in this regard is Michael Porter's approach. This is 
reflected in a policy toolkit sponsored by the World Economic Forum, namely, the Global Competitiveness Index of ranking and benchmarking countries (Sum 2009; see also Kantola 2006; Davis et al., 2012). This has a distinctive technological selectivity based on technologies of hierarchization, performance and judgement. It grades countries in terms of their economic performance and renders the world knowable through the rank ordering of countries. In neo-Foucauldian terms this involves a neoliberal disciplinary technology that operates as a 'paper panopticon' to visibilize countries and problematize policy areas. It normalizes a competitiveness truth regime and legitimates power to intervene and regulate lives in a marketfriendly direction. Such disciplinary toolkits and their status as a global knowledge brand have met strong resonance in Asia. The competitiveness toolkit is used to reveal the strengths/weakness of countries and it has been recontextualized in policy documents as 'catch up competitiveness' - a panacea for further development in the region (e.g., the ADB's Asian Development Outlook 2003).

Following the failure to roll out global competition law through the WTO, the ADB acted to selectively hybridize and thicken the competitiveness 'knowledge brand' by promoting the conditions for more effective competition. The mantra of 'Competition for Competitiveness' (meaning domestic competition for international competitiveness) is discernible in the policy documents of the ADB and ADBI (Asian Development Bank Institute). In the Report and Proceedings of the ADB's Competition Law and Policy Roundtable meeting on the 16 and 17 May in 2006 in New Delhi (see table 2), 'competition' and 'competitiveness' were used as the title of both the Preface and of the IMD Index, illustrating the importance (and the power) of 'competitiveness' in disciplinary-classificatory-hierarchical terms (Sum 2009). Within this report, one contributor, $\mathrm{Dr}$ V. Krishnamurthy (Chair of India's National Manufacturing Competitiveness Council) was quoted as saying that '[c]ompetition laws trigger competitiveness; they provide the framework necessary to achieving competitiveness' (ADB 2006). He continued: 'competition laws provide the necessary framework for competitiveness as "final effects"' (ADB 2006: 8). Such narratives introduces a means-ends relation to competition law with a view to giving 'hope' to countries and regions that there is a clear and almost fool-proof path for them to follow to enhance their competitiveness. 


\section{Technological selectivity of 'Competition for Competitiveness': toolkits and workshops}

This means-end relation between competition (law) and 'competitiveness' underpins a functional-cum-pragmatic reasoning that supports regional strategizing and planning. The same document reported that Allan Fels, Dean of the Australia and New Zealand School of Government, highlighted the importance of a 'Competition Policy Strategy Model' in claiming 'that regulatory institutions as well as the judiciary need capacity building and international "technical assistance" can play an important role in this regard' (ADB 2006: xv). These twin emphases on 'capacity building' and 'technical assistance' mark the influence of new managerial knowledge on pro-poor competition law and policy is implemented at the level of everyday institutional practices. Some insights into what is at stake here can be drawn from Craig and Porter's examination of World Bank project implementation in Vietnam, Uganda, Pakistan, and New Zealand (Craig and Porter 2006). They argued that 'new institutional economics' visibilizes the institutional gaps and can provide technicalmanagerial tools for intervention and, in the cases that they examined, this produced a three-pronged plan for intervention encapsulated in the slogan: 'Inform, Enforce, Compete' (Craig and Porter 2006: 102). Considering these elements in turn indicates how implementing this policy framework in the Asian region serves to intensify disciplinary and governmentalizing power and its effects.

First, 'inform' refers to the way the ADB provides information about competition law -in the form of an on-line 'toolkit'. Introduced in 2006, the "Competition Law Toolkit" (ADB 2007; Figure 2), is part of the ADB's regional legal-managerial technologies that are designed to realize the objectives. This toolkit has many elements. By way of illustration, let us consider its 'Overview of Practices Controlled by Competition Law' (ADB Website 2007). This reveals a shift in rhetoric from an emphasis on 'competition-competitiveness' to a rational-economic focus on what is simply 'beneficial' or 'harmful' to the competition process (see Table 2 above). By identifying 'harm/benefit' intensifies, this knowledging technology governmentalizes power by providing a form of easily applied, diagnostic knowledge that provides an easy assessment grid that distinguishes between good and bad competition practices; 
brings regional-national actors into the competition-law fold; and guides formative judgements and related 'soft' policy recommendations (see table 3).

Figure 2: Asian Development Bank's Competition Law Toolkit

\section{$\mathrm{ADB}$ Asian Development Bank}

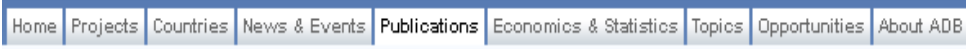

\section{Catalog}

tome D Publications D Catalog D Online Publications D Document

\section{Competition Law}

Toolkit

Updated: 18 January 2007

- Purpose and Structure of the Toolkit

- Overview of Practices Controlled by Competition Law

- Countries with Competition Law Systems

- Benefits of Competition Policy

- Practices Controlled by Competition Law

- Key Concepts and Tools
- Competition, Privatization, and Regulation

- Emerging Economies

- Enforcement Mechanisms

- ADB Resources and Project

- Other Resources

- Glossary and List of Abbreviations

(Source: ADB website http://www.adb.org/Documents/Others/OGC-

Toolkits/Competition-Law/default.asp), last accessed 10 May 2014

In addition, the toolkit provides programmes for technical assistance and specifies the appropriate enforcement mechanisms, which include independent competition authorities, the role of courts and 'administrative guidance', etc. This way of mapping the legal-managerial organizations, technical assistance and procedures subject regional and national actors to formalist-disciplinary designs of competition law.

Table 3: Overview of Competition Law Practices: Harms, Benefits and Recommendations

\begin{tabular}{|l|l|l|l|}
\hline Practices & Harms & Benefits & $\begin{array}{l}\text { Recommended } \\
\text { Actions }\end{array}$ \\
\hline Anti-competitive & III effects of & Competitive & Regulation \\
\hline
\end{tabular}




\begin{tabular}{|l|l|l|l|}
\hline $\begin{array}{l}\text { agreements } \\
\text { (e.g., price fixing, } \\
\text { output restriction) }\end{array}$ & $\begin{array}{l}\text { preventing, } \\
\text { restricting and } \\
\text { distorting } \\
\text { competition }\end{array}$ & $\begin{array}{l}\text { markets are } \\
\text { beneficial to } \\
\text { consumer } \\
\text { welfare }\end{array}$ & \\
\hline $\begin{array}{l}\text { Abusive behaviour } \\
\text { (e.g., monopoly or } \\
\text { dominant firm) }\end{array}$ & $\begin{array}{l}\text { Predatory pricing } \\
\text { of dominant firms } \\
\text { or monopolists }\end{array}$ & $\begin{array}{l}\text { Benefits of } \\
\text { competition } \\
\text { (allocative } \\
\text { efficiency) }\end{array}$ & $\begin{array}{l}\text { De-monopolization } \\
\text { Regulation }\end{array}$ \\
\hline $\begin{array}{l}\text { Mergers (e.g., } \\
\text { merges of } \\
\text { independent firms) }\end{array}$ & $\begin{array}{l}\text { Reduce rivalry of } \\
\text { firms in the } \\
\text { market, with } \\
\text { detrimental } \\
\text { consequences for } \\
\text { consumer welfare }\end{array}$ & $\begin{array}{l}\text { Competitive } \\
\text { markets are } \\
\text { beneficial to } \\
\text { consumer } \\
\text { welfare }\end{array}$ & Regulation \\
\hline $\begin{array}{l}\text { Public restrictions } \\
\text { on competition } \\
\text { (e.g. state } \\
\text { subsidies, } \\
\text { licensing rules) }\end{array}$ & $\begin{array}{l}\text { State distorting } \\
\text { competition }\end{array}$ & $\begin{array}{l}\text { Benefits of } \\
\text { market power } \\
\text { (allocative and } \\
\text { productive } \\
\text { efficiency) }\end{array}$ & $\begin{array}{l}\text { Privinvestment } \\
\text { Regulation }\end{array}$ \\
\hline
\end{tabular}

(Source: Author's compilation from the ADB website on Competition Law Toolkit http://www.adb.org/Documents/Others/OGC-Toolkits/Competition-

Law/complaw020000.asp) last accessed 10 May 2014

Second, the 'enforce' part of Craig and Porter's framework is evident in the selective deployment of managerial practices that build institutions and strengthen the technical expertise of law providers. An example is the training workshops organized by the Asian Development Bank Institute (ADBI) (the executive arm of the ADB) together with the US Federal Trade Commission (USFTC), OECD, and the ASEAN Secretariat. Their third AEGC [ASEAN Expert Group on Competition] Workshop on 'Costs and Benefits of Competition Policy, Law and Regulatory Bodies' in Kuala Lumpur on 18-19 May 2009 was 'part of the capacity building program to assist ASEAN countries to develop and harmonize competition laws and policies by 2015' (ADBI 2009, Figure 3). 
Figure 3: The $3^{\text {rd }}$ AEGC Workshop on Competition Law/Policy 2009
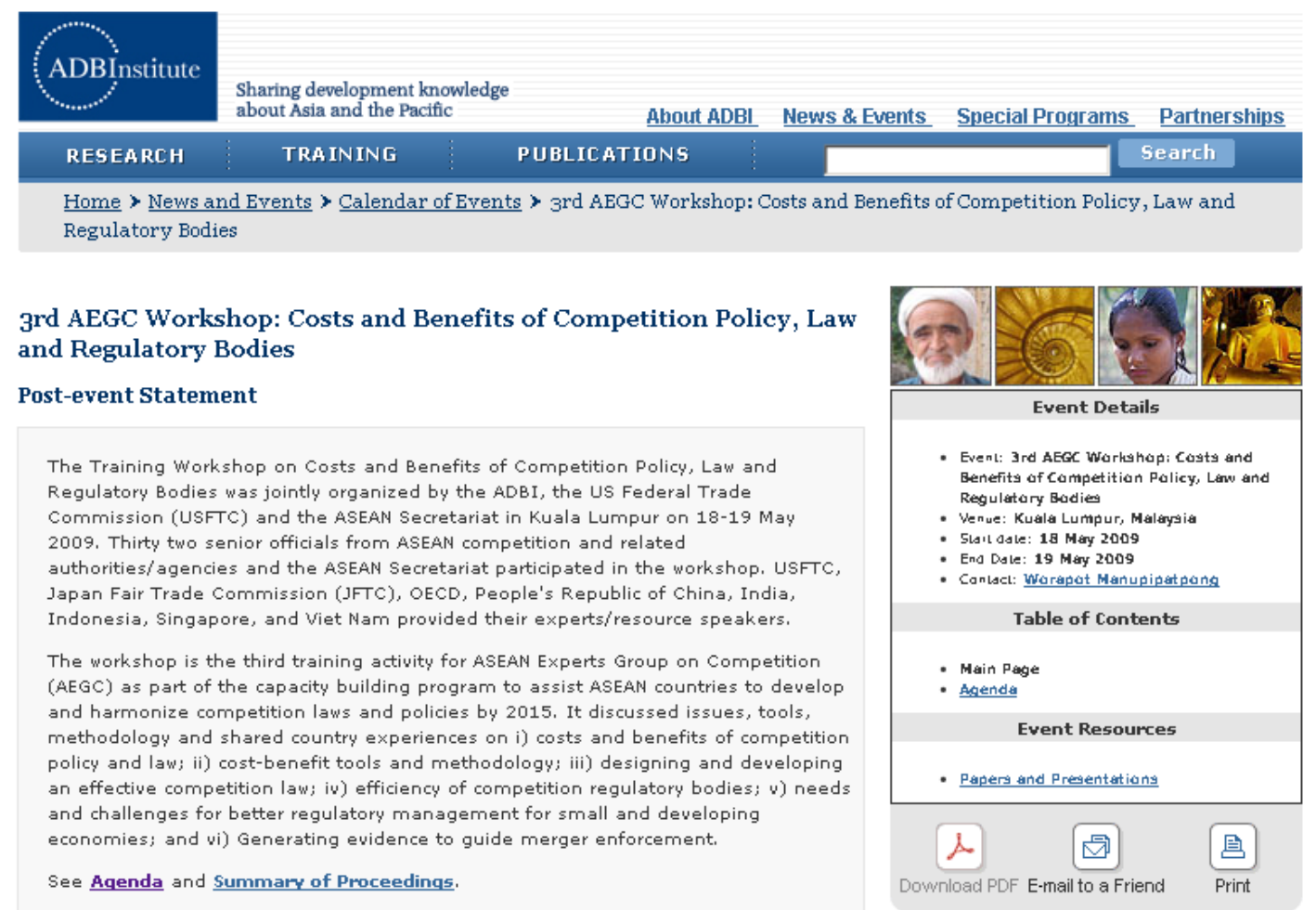

(Source: ADBI Website, http://www.adbi.org/event/3070.3rd.aegc.workshop/ Last accessed 10 May 2014)

Training workshops to build 'competition/competitiveness' institutions and best practices serve to normalize competition law/policy as well as to construct and manage communities of legal stakeholders. Each workshop comprised 'about 30 mid-senior government officials and representatives of competition and related agencies in ASEAN member countries and the ASEAN Secretariat' (ADBI 2009). They were encouraged to adopt 'best practices' to assess the regulatory impact of competition laws and policy. 'Best practices' were codified in cost-benefit terms; and target groups were encouraged to become learning subjects who should overcome their lack of competition-competitive know-how. These cost-benefit modes of 
calculation contributed towards the shaping of 'choices' and elicited particular modes of support and advocacy for competitive practices based on cases.

In neo-Foucauldian terms, the technological selectivity of such toolkits and workshops can be interpreted as 'apparatuses of rule'. They involve microtechnologies of steering, assessment and capacitation that target and 'assist' states, firms, mid-ranking officials, and delegates of related agencies, who are steered towards accepting and promoting a competitiveness order based on marketcompetition calculations. These targets are encouraged to learn and adopt skillbased toolkits and best practices with regards to regulatory design, advocacy and assessment. These micro-technologies guide and influence their conduct in line with the neo-liberal visions of competitive usefulness among 'experts' on competition law and policy. These intensify the mode of ruling over everyday policy life and are designed to 'change hearts and minds of actors and stakeholders in policy, plan and programme procedures' (Marshall and Fisher 2006: 284; cf. Cammack 2014) but this does not occur without contradictory consciousness, tensions, and contestations.

Third, the 'compete' part of Craig and Porter's framework refers in the Asian case to the promotion of market forces and market-friendly mentalities via the integration of pro-competition rules into understandings of good governance in general and norms of corporate governance in particular. The intention behind this agenda is that this mode of 'governing at a distance' will limit the scope for cronyism, corruption, and bureaucratic inefficiencies, both through the institution of 'new rules of the game' and through internalization and self-regulation. By generalizing rules, norms, and practices of good corporate governance, it is narrated that competition will be fostered, opportunities for rent-seeking behaviour reduced, and reciprocal monitoring and self-monitoring encouraged. This technology of competition-competitiveness is extended beyond a commitment to the rule of law in a narrow juridico-political sense to include the creation of individual and corporate subjects who value a level-playing field, especially when it comes to the procurement and delivery of public services. Where successful, these governing technologies help to intensify the penetration of norms of competition-competitiveness into the everyday life of the region. Of particular importance is the penetration of these norms into the micro-pores of 
society, introducing the ideology of competitiveness into local economies that are subjected to negotiations and adjustments.

\section{The contingent dispositivization of a disciplinary and governmentalized socioeconomic-legal (dis-)order}

The interaction among these modes of selectivity serves to regularize and sediment competition-competitiveness subjectivities that are performed, repeated and stabilize over time. As forms of discourses, knowledging apparatuses, genre chains, knowledging technologies and strategic logics (see Table 4), they become regularized through administrative strategies and judicial institutions. Such dispositivization of competitiveness, competition and competition law is understood in terms of how they are selected, assembled and consolidated in Asia after the Doha Round. Participating stakeholder subjects are disciplined (via index) and governmentalized (via technologies of capacitation and [self-]rule) to become a part of the competitive-competition socioeconomic-legal (dis-)order.

Table 4 Structural Contexts and Modes of Selectivity in the Making of the Competitiveness-Competition Socioeconomic-Legal (Dis-) Order

\begin{tabular}{|c|c|c|c|}
\hline Structural Contexts & Agential Selectivity & $\begin{array}{l}\text { Discursive } \\
\text { Selectivity }\end{array}$ & $\begin{array}{l}\text { Technological } \\
\text { Selectivity }\end{array}$ \\
\hline $\begin{array}{l}1997 \text { Asian Crisis } \\
\text { that raised doubts } \\
\text { on market-based } \\
\text { neoliberalism } \\
\text { Failure of Doha to } \\
\text { include competition } \\
\text { policy in its trade } \\
\text { negotiation } 2004 \\
\text { - Beyond Doha } \\
\text { and the WTO } \\
\text { - World Bank } \\
\text { Asian }\end{array}$ & $\begin{array}{l}\text { Organic } \\
\text { intellectuals: } \\
\text { World Bank } \\
\text { President, Chief } \\
\text { Economist and } \\
\text { their supporting } \\
\text { teams, Asian } \\
\text { Development } \\
\text { Bank, policy } \\
\text { councils, schools } \\
\text { of } \\
\text { law/government }\end{array}$ & $\begin{array}{l}\text { - Privileging pro- } \\
\text { poor growth and } \\
\text { competition } \\
\text { - Selecting familiar } \\
\text { discourses and } \\
\text { knowledge brand } \\
\text { (e.g., } \\
\text { competitiveness) } \\
\text { - Genre chain of } \\
\text { poverty } \\
\text { reduction, } \\
\text { competitiveness, } \\
\text { competition and } \\
\text { competition } \\
\text { policy/law }\end{array}$ & $\begin{array}{l}\text { Technology of } \\
\text { performance and } \\
\text { hierarchization } \\
\text { Technology of } \\
\text { capacitation and } \\
\text { (self-)rule }\end{array}$ \\
\hline
\end{tabular}




\begin{tabular}{|l|l|l|l|}
\hline Development & $\bullet \begin{array}{l}\text { Reports, policy } \\
\text { Bank (regional } \\
\text { counterpart) }\end{array}$ & outlook, index, & \\
& & roundtable, \\
& toolkits, & \\
& workshop and & \\
& technical & assistance & \\
& & & \\
\hline
\end{tabular}

(Source: Author's compilation)

In Asia, the gains of this contingent dispositivization of this new socioeconomic-legal (dis-)order on competitiveness and competition are unevenly distributed. It has benefitted some social forces (e.g., transnational investors, academic/professional brokers/ practitioners, etc.) more than others (e.g., domestic state-owned capital). Thus its implementation faces resistance from domestic business capital especially those that are tied to state-dominated mode of growth (e.g., chaebols in South Korea and government-owned companies in Singapore) and the real estate sector. Ultimately, competition law remains a site of negotiation and contestation. Particular sectors or state-owned companies negotiated their 'exemption' statuses and resistance groups negotiate the meanings of the social and/or contestation via the social (e.g., the call for pro-poor redistribution and not pro-poor growth).

\section{Concluding remarks}

This article employed CPE to interpret and explain competition, competitiveness and competition law/policy. Theoretically, CPE steers a course between one-sided constructivist cultural turns and more structuralist analyses of economic categories and system dynamics. This course is guided by the co-evolution of (1) sense- and meaning-making and (2) the contingent structuration of social relations. This coevolution is also shaped by technological and agential selectivities. This general approach builds on a virtual dialogue among Marx, Gramsci and Foucault in which each contributes key ideas and also provides fruitful qualifications to the arguments and insights of the other.

Empirically, CPE has been applied to examine how the World Bank and Asian Development Bank extend neoliberal hegemony in the context of the constraints and 
opportunities opened up by the Asian Crisis and the failure of the Doha Round. The discourses of 'new institutional economics', knowledge sharing, competitiveness, pro-poor and competition were translated it into practices that focus attention on and reinforce the status of competitiveness and competition policy as an object of governmentality, that create new competitive subjects, that steer it through new governmental technologies, and that assemble new dispositives. Based on discursive and technological selectivities, the ability of the President and Chief Economist of the World Bank to make a difference in this conjuncture indicates the importance of agential selectivity as well as the importance of their interpretive authority within the World Bank and Asian Development Bank as part of the leading Bretton Woods institution. These agents selectively rolled out their institutional and pro-poor reading of development and strategically promoted the discourses of knowledge bank, poverty reduction, competitiveness and competition. Reports and outlooks knitted together genres each of which had its own selectivity. The discursive selectivity of the World Bank-/Asian Development Bank-related genre chain expanded the meaning of competitiveness to include poverty reduction as both precondition and outcome but also limited the meaning of competition as a development tool best enhanced via competition policy/law. The density of this chain was further enhanced via knowledging technologies and apparatuses such as index, roundtable, toolkits, workshop, cost-benefit practices and technical assistance. Crucial here were the discursive and technological selectivities that allowed for the dispositivization of a regional socioeconomic-legal (dis-)order in Asia. One of its distinctive features was its use of competition as an economic development tool that emphasizes the need to get 'competition policy/law right' and links this to a purportedly pro-poor agenda. This aims to benefit the poor by boosting growth via effective competition policy and rests on the articulation of capital, development knowledge, and legal and managerial-professional practices that converge in a neoliberal direction. These discourses, institutions, technologies and practices contribute to the naturalization and reproduction of a new round of market reorganization that opens the domestic market for foreign capital in the name of reducing entry barriers, opening local monopolies to competition, and securing the benefits on the grounds that these measures would all boost competition and thereby reduce poverty. 
These post-Washing Consensus proposals are contested by several forces on the basis of their different positions in the circuits of capital as well as within the wider society. Regarding the former, while some groups seek to negotiate 'exemptions' for particular sectors or state-owned companies; others challenge whether competitiveness applies to firms, nations or regions and, if so, whether it depends on subordinating all social relations directly or indirectly to market forces in the name of creating a market-friendly environment and boosting development. This pro-poor rhetoric is essentially a pro-market ideology that conflates growth and poverty reduction and ignores the need for active social redistribution to compensate for market-generated polarization. The role of social forces and NGOs in challenging this approach is a topic for another paper.

\section{Acknowledgment}

The author thanks Michael Dowdle from the National University of Singapore for his encouragement to apply the CPE approach to competition policy/law; and Eva Hartman from Copenhagen Business School and two anonymous referees for their comments on this article. I also want to thank Gigi Chen and Helen Fu for their support and friendship while finishing this paper in Hong Kong.

\section{Disclosure statement}

No potential conflict of interest was reported by the author

\section{Notes}

${ }^{1}$ This does not mean that the real (social) world exists outside discourse: it means only that there it has objective features that exist and constrain action, whether or not specific subjects and discourses refer to them. To believe otherwise is to assert that the real world exists only to the extent that it is the subject of discourse.

${ }^{2}$ According to Fairclough (2003), genre chains are genres which are regularly and predictably chained together such that meanings are moved and transformed along the chain, and recontextualized and transformed in regular ways in accordance with recontextualizing principles (e.g., exclusion).

\section{Notes on contributors}


Ngai-Ling Sum is Reader in Cultural Political Economy and Co-Director of the Cultural Political Economy Research Centre, Lancaster University, UK. She studied Economics at Birmingham University, received her PhD in Sociology from Lancaster, and has since worked in Sheffield, Manchester, and Lancaster Universities. Her recent work includes: Beyond the Regulation Approach: Putting the Economy in its Place in Political Economy (2006, co-authored with Bob Jessop), Towards a Cultural Political Economy: Putting Culture in its Place in Political Economy (2013, coauthored with Bob Jessop), many book chapters, and articles in journals such as Capital and Class, Competition and Change, Critical Asian Studies, Critical Policy Studies, Development Studies, Economy and Society, Journal of the Knowledge Economy, Journal of Language and Politics, New Political Economy, Urban Studies. Her homepage is www.lancaster.ac.uk/fass/ppr/profiles/Ngai-Ling-Sum/

\section{References}

Altay, S. 2011. Hegemony, private actors, and international institutions:

Transnational corporations as the agents of transformation of the trade regime from GATT to the WTO, PhD thesis, University of Trento and University of Kassel. http://eprints-phd.biblio.unitn.it/581/, last accessed 5 May 2015.

Andersen, N. 2003. Discourse analytical strategies: Foucault, Koselleck, Laclau, Luhmann. Bristol: Policy Press.

Asian Development Bank 2003. Asian Development Outlook 2003: Competitiveness in Developing Asia, New York: Oxford University Press.

Asian Development Bank 2006. Report and proceedings of the ADB's competition law and policy roundtable meeting on the $16^{\text {th }}$ and $17^{\text {th }}$ of May in 2006 in New Delhi.

Asian Development Bank. 2007 Website 1.

http://www.adb.org/Documents/Others/OGC-Toolkits/Competition-

Law/default.asp, last accessed 10 February 2012.

Asian Development Bank Institute 2009. Report on workshop. See

http://www.adbi.org/event/3070.3rd.aegc.workshop, last accessed 10 May 2014.

Beeson, M. and R. Robison 2000. Interpreting the Crisis. In Politics and Markets in 
the Wake of the Financial Crisis, ed. M. Besson et al., 3-24. London: Routledge. Blyth, M. 2002. Great transformations: Economic ideas and institutional change in the twentieth century. Cambridge: Cambridge University Press.

Caborn, J. 2007. On the Methodology of Dispositive Analysis. Critical approaches to discourse analysis across disciplines 1, no. 1: 115-123.

Cammack, P. 2003. What the World Bank Means by Poverty Reduction, retrieved from

http://www.albacharia.ma/xmlui/bitstream/handle/123456789/31572/1375What \%20the\%20World\%20Bank\%20Means\%20by\%20Poverty\%20Reduction2003. pdf? sequence $=1$, last accessed $8^{\text {th }}$ May 2015.

Cammack, P. 2014. World Development Report 2015: Programming the poor. Working Paper Series: The Multilaterial Development Banks and the Global Financial Crisis. Working Paper 7. Southeast Asia Research Centre, Hong Kong: City University.

Craig, D. and D. Porte. 2006. Development beyond neoliberalism? Governance, poverty reduction and political economy. London: Routledge.

Davis, K.E., B. Kingsbury and S.E. Merry 2012. Indicators as a technology of global governance. Law and Society Review 41: 71-104.

Fairclough, N. 2003. Analyzing discourse, London: Routledge.

Foucault, M. 1977. The confession of the flesh. In Power/Knowledge selected interviews and other writings, ed. C. Gordon, 1980, 194-228. New York: Pantheon Books

Foucault, M. 1995. Discipline and punish: The birth of the prison. London: Vintages Book.

Foucault, M. 1991. Governmentality. In The Foucault effect: Studies in governmentality, ed. G. Burchell, C. Gordon and P. Miller, 87-104. London: Harvester Wheatsheaf.

Foucault, M. 2008a. Security, territory, population, lectures at the Collège de France, 1977-78. Basingstoke: Palgrave.

Foucault, M. 2008b. The birth of biopolitics: Lectures at the Collège de France 197778. Basingstoke: Palgrave.

Gramsci, A. 1971. Selection from the Prison Notebooks. London: Lawrence \& Wishart.

Green, M., ed. 2011. Rethinking Gramsci, London: Routledge. 
Harvey, D. 2005. A brief history of neoliberalism. Oxford: Oxford University Press. International Bank for Reconstruction and Development/World Bank. 2004. The world development report 2005: A better investment world for everyone. Washington DC: World bank and New York: Oxford University Press. Ives, P. 2004. Gramsci's politics of language. Toronto: University of Toronto Press. Jäger, S and F. Maier 2009. Theoretical and methodological aspects of Foucauldian critical discourse analysis and dispositive analysis. In Methods for Critical Discourse Analysis, ed, R. Wodak and M. Reisigl, 34-61. London: SAGE. Jessop, B. 2010. Another Foucault effect? Foucault on governmentality and statecraft. In Governmentality: Current issues and future challenges, ed. U. Blockling, S. Krasmann and T. Lemke, 239-48. London: Routledge.

Jessop, B. and N-L. Sum. 2006. Beyond the regulation approach. Cheltenham: Edward Elgar.

Kantola, A. 2006. Transforming political imaginaries: The use of competitiveness. Department of Communication, University of Helsinki Working Paper 3/2006. Laclau, E. and C. Mouffe. 1985. Hegemony and socialist strategy. London: Verso. Link, J. 1983. Elementare Literatur und generative Diskursanalyse. Munich: Wilhelm Fink Verlag.

Lundvall, B-Å., ed. 1992. National systems of innovation: Towards a theory of innovation and -interactive learning. London: Pinter.

Marsden, R. 1999. The nature of capital: Marx after Foucault. London: Routledge. Marshall, R. and T.B. Fischer. 2006. Regional electricity transmission planning and SEA. Journal of Environmental Planning and Management, 49: 279-99.

Murphy, J. 2007. The World Bank and global managerialism. London: Routledge. North, D.C. 1990. Institutions, institutional change, and economic performance. Cambridge: Cambridge University Press.

Peck, J. and Theodore, N. 2015. Fast policy: Experimental statecraft at the thresholds of neoliberalism. Minneapolis: University of Minnesota Press.

Plehwe, D. and B. Walpen, eds. 2006. Neoliberal hegemony: a global critique. London: Routledge.

Porter, M. 1990. The competitive advantage of nations. New York: Free Press.

Rooney, D 1997. A contextualising, socio-technical definition of technology: Learning from Ancient Greece and Foucault.. 
http://citeseerx.ist.psu.edu/viewdoc/download?doi=10.1.1.115.408\&rep=rep1\&typ $\underline{e=p d f}$, last accessed on 5 May 2015.

Saad-Filho, A. and D. Johnson, eds. 2004. Neoliberalism: A critical reader, London: Pluto Press.

St. Clair, A.L. 2006. Global poverty: The co-production of knowledge and politics. Global Social Policy 6: 57-77.

Stiglitz, J. 1989. The economic role of the state. Oxford: Blackwell.

Stiglitz, J. (edited with a commentary by Chang, H-J.) 2001. Joseph Stiglitz and the World Bank: The rebel within. London: Anthem Press.

Sum, N-L. 2009. The production of hegemonic policy discourses: 'Competitiveness' as a knowledge brand and its (re-)contextualizations. Critical Policy Studies 3: 50-76.

Sum, N-L. and B. Jessop. 2013. Towards a cultural political economy. Cheltenham: Edward Elgar.

Taylor, M. and S. Soederberg. 2007. The King is dead (long live the King?): From Wolfensohn to Wolfowitz at the World Bank. In D. Moore, ed., The World Bank: Development, poverty, hegemony, 453-478. Scottsville: University of KwaZuluNatal Press.

Thomas, P. 2009. The Gramsci moment: Philosophy, hegemony and Marxism. Leiden: Brill.

Wade, R. 2001. Showdown at the World Bank. New Left Review 7, Jan-Feb: 124-37. Wenger, E. 1999. Communities of practice: Learning, meaning and identity. Cambridge: Cambridge University Press.

Wolfenson, J. 1998. The other crisis. Address by the President of the World Bank Group to the Board of Governors of the World Bank Group at the 1998 Annual Meeting, Washington D.C.. Press Release No. 3, Oct 6-8. http://www.imf.org/external/am/1998/speeches/pr03e.pdf, last accessed on 5 May 2015. 